\title{
Isolation and Identification of Indigenous Lactic Acid Bacteria from North Sumatra River Buffalo Milk
}

\author{
Rizqiati $\mathrm{H}^{1}$, Sumantri $\mathrm{C}^{2}$, Noor $\mathrm{RR}^{2}$, Damayanthi $\mathrm{E}^{3}$, Rianti $\mathrm{EI}^{4}$ \\ ${ }^{I}$ Graduate of Department of Animal Production and Technology, Bogor Agricultural University, Bogor 16680 \\ ${ }^{2}$ Department of Animal Production and Technology, Faculty of Animal Science, Bogor Agricultural University, Bogor 16680 \\ ${ }^{3}$ Department of Community Nutrition, Faculty of Human Ecology, Bogor Agricultural University, Bogor 16680 \\ ${ }^{4}$ ICABIOGRAD, Kampus Penelitian Pertanian Cimanggu, Bogor, Jl. Tentara Pelajar 3A, Bogor 16111 \\ E-mail:heni.rizqi@gmail.com \\ (received 04-05-2015; revised 25-06-2015; accepted 29-06-2015)
}

\begin{abstract}
ABSTRAK
Rizqiati H, Sumantri C, Noor RR, Damayanthi E, Rianti EI. 2015. Isolasi dan identifikasi bakteri asam laktat indigenus susu kerbau sungai Sumatera Utara. JITV 20(2): 87-94. DOI: http://dx.doi.org/10.14334/jitv.v20i2.1163

Susu kerbau merupakan salah satu sumber bakteri asam laktat (BAL) yang berpotensi sebagai kultur untuk starter maupun probiotik. Penelitian ini bertujuan untuk mengisolasi dan mengidentifikasi BAL asal susu kerbau sungai Sumatera Utara, serta menguji ketahanannya pada $\mathrm{pH}$ rendah. Bakteri asam laktat diisolasi dan ditumbuhkan pada medium De Man Rogosa Sharpe Agar (MRSA). Isolasi dilakukan sampai diperoleh kultur murni. Identifikasi BAL dengan pengujian karakteristik morfologi, fisiologi dan biokimia. Karakteristik morfologi dilakukan dengan pewarnaan Gram dan melihat bentuk sel. Karakteristik fisiologi dilakukan dengan uji ketahanan pada $\mathrm{pH} 4,5$ dan suhu $45^{\circ} \mathrm{C}$. Karakteristik biokimia dilakukan dengan uji produksi $\mathrm{CO}_{2}$, $\mathrm{NH}_{3}$ dan dekstran. Pengujian sifat probiotik dilakukan dengan menguji ketahanan isolat BAL pada pH rendah. Pengujian dengan kit API tes CHL 50 untuk mengetahui jenis spesies dari sepuluh BAL terpilih. Hasil identifikasi diperoleh 41 isolat BAL, yang secara umum memiliki karakterisitik Gram positif, katalase negatif, berbentuk batang dan bulat. Pengujian ketahanan BAL pada $\mathrm{pH}$ rendah $(\mathrm{pH} 2)$ menunjukkan penurunan jumlah populasi sebanyak $1,24 \pm 0,68 \mathrm{log} \mathrm{cfu} / \mathrm{ml}$. Isolat terbaik dari pengujian ketahanan pada $\mathrm{pH}$ rendah adalah isolat L12, L16, L17, L19, L20, M10, P8, S3, S19 dan S20. Hasil pengujian dengan API test CHL 50 pada sepuluh isolat terpilih tersebut menunjukkan ada empat spesies BAL dari susu kerbau sungai Sumatera Utara, yaitu Lactobacillus plantarum, L. brevis, L. pentosus dan Lactococus lactis.
\end{abstract}

Kata Kunci: Susu Kerbau, BAL, Isolasi, Identifikasi

\begin{abstract}
Rizqiati H, Sumantri C, Noor RR, Damayanthi E, Rianti EI. 2015. Isolation and identification of indigenous lactic acid bacteria from North Sumatra river buffalo milk. JITV 20(2): 9-16. DOI: http://dx.doi.org/10.14334/jitv.v20i2.1163

Buffalo milk is a source of various lactic acid bacteria (LAB) which is potential as culture starter as well as the probiotic. This study was conducted to isolate and identify LAB from indigenous North Sumatra river buffalo milk. Lactic acid bacteria was isolated and grown in medium De Man Rogosa Sharpe Agar (MRSA). The isolation was conducted to obtain pure isolate. The identification of LAB was studied in terms of morphology, physiology, biochemistry and survival on low pH. Morphology tests were conducted by Gram staining and cell forming; physiology tests were conducted for growing viability at $\mathrm{pH} 4.5$ and temperature at $45^{\circ} \mathrm{C}$; whereas biochemistry tests were conducted for $\mathrm{CO}_{2}$, dextran and $\mathrm{NH}_{3}$ productions. Determination of LAB species was conducted using Analytical Profile Index (API) test CHL 50. Results of identification showed that 41 isolates were identified as LAB with Gram-positive, catalase-negative, rod and round shaped characteristics. Resistance test done to low $\mathrm{pH}$ $(\mathrm{pH} 2)$ for the lactic acid bacteria showed decrease of bacteria viability up to $1.24 \pm 0.68 \mathrm{log} \mathrm{cfu} / \mathrm{ml}$. The resistant isolates at low pH were L12, L16, L17, L19, L20, M10, P8, S3, S19 and S20. Identification with API test CHL 50 for 10 isolates showed that four isolates were identified as Lactobacillus plantarum, L. brevis, L. pentosus and Lactococuslactis.
\end{abstract}

Key Words: Buffalo Milk, LAB, Isolation, Identification

\section{INTRODUCTION}

Milk is one of food stuffs that naturally containing Lactic Acid Bacteria (LAB) which is generally used for culture starter forming various processed food products. The LAB originated from milk is also potentially developed into probiotic for functional food development. Probiotic was life bacteria, given as food and feed supplement which have beneficial effects for health of both human and animals by improving intestinal microflora balance (Roberfroid 2000). Study of LAB's potential as probiotic of indigenous materials are continuously done, especially to be used as functional food. 
$\mathrm{LAB}$ isolation of various milk had been done, among others from raw cow milk (Abdullah \& Osman 2010), goat milk (Tserovska et al. 2002; Setyawardani et al. 2013), Bima horse milk (Antara et al. 2009), wild horse milk (Sugitha et al. 2011), Sumbawa horse milk (Sujaya et al. 2008), sheep milk (Iranmanesh et al. 2012), camel milk (Ahmed et al. 2002; Khedid et al. 2009; Abbas \& Mahasneh 2015), and breast milk (Nuraida et al. 2011). LAB isolation of fresh buffalo milk was done in India, Pakistan and Egypt both of fresh buffalo milk or produced buffalo milk products (Aziz et al. 2009; Tambekar et al. 2009; Singh \& Sharma 2009; Patel \& Patel 2012; Sharma et al. 2013; Shafakatullah \& Chandra 2014; Kumar et al. 2014). In Indonesia, $\mathrm{LAB}$ isolation from the produced buffalo milk products had been done to produce a product of West Sumatran buffalo called "dadih" (Surono 2003; Sunaryanto \& Marwoto 2013), whereas isolation and identification of LAB from fresh buffalo milk in Indonesia has not been much done.

North Sumatra river buffalo is one of genetic sources of Indonesian local animal which has not been explored. River buffalo milk production could reach 8 liter/day. Its quality was better compared to cow milk, where in the content of protein and fat was higher but its cholesterol content was lower (Damayanthi et al. 2014). Exploration of LAB from North Sumatra river buffalo and its utilization to produce the culture starter of probiotic product currently have not been much reported. This LAB exploration was first step to get probiotic bacteria candidate by testing several probiotic characteristics (Rizqiati et al. 2015); in further it was applied in mozzarella cheese into probiotic mozzarella cheese with North Sumatra river buffalo milk as raw material.

One condition for microorganism called as probiotic was its capability to survive in intestinal track condition such as endurance to low $\mathrm{pH}$ and bile salt (Nuraida et al. 2011). The first exposure of probiotic when entering the intestinal track was a gastric with $\mathrm{pH}$ around 2 . Endurance test to low $\mathrm{pH}$ was needed to determine whether the LAB culture was survive in the gastric acid or not (Wildman \& Medeiros 2000).

This study was aimed to isolate the LAB from North Sumatra river buffalo milk and identify it based on morphology, physiology, biochemical, and identify species of the LAB. Besides, this study was aimed to select LAB isolate which could survive in low $\mathrm{pH}(\mathrm{pH}$ 2) which was one of probiotic characteristic tests. Isolation and identification results of $\mathrm{LAB}$ became first step of selection of LAB from North Sumatra river buffalo milk as a probiotic.

\section{MATERIALS AND METHODS}

Materials used in this study were 24 samples of river buffalo milk from 4 locations of buffalo farming in North Sumatra, namely: Lubuk Pakam, Medan, Patumbak, and Siborong-borong where from each location was taken 6 samples. The milk samples were brought in cold sterile tube in the cooling box to the Integrated Laboratory of Faculty of Animal Science of Bogor Agricultural University. Conducted tests were isolation and identification of $\mathrm{LAB}$ from the river buffalo milk. The isolation was done using media De Man Rogosa Sharpe (MRS). LAB identification consisted of characteristic of morphology, physiology, and biochemical. Characteristic tests of the probiotic were done by testing $\mathrm{LAB}$ resistance to low $\mathrm{pH}$. LAB identification by API test CHL 50 was done to determine its species.

\section{LAB isolation}

LAB isolation technique referred to Khedid et al. (2009) which was modified. The buffalo milk samples $(10 \mathrm{ml})$ was taken aseptically and inserted into $90 \mathrm{ml}$ of sterile physiological $\mathrm{NaCl}$ solution $(0.85 \%)$, and further it was done a gradual dilution into $10^{5}$ dilutions. One $\mathrm{ml}$ diluted sample was distributed on MRS agar (MRSA) media containing of bromo cresol purple (BCP) $0.01 \%$ on petridish, and then the samples were incubated anaerobically for 24 hours at $37^{\circ} \mathrm{C}$. LAB colony seemed as colony which was surrounded by yellow zone, and further that colony was taken and scratched on MRSA media. That scratching was done continuously to obtain one pure colony.

\section{Morphology characteristic to identify the LAB}

Characterizing of cell morphology was aimed to see isolate form and Gram staining characteristic. Cell form was viewed by microscope and done after the Gram staining. Cell morphology expected was positive Gram with tube or oval cell (Iranmanesh et al. 2012).

\section{Physiology characteristic to identify the LAB}

Physiology characteristic test to identify the LAB consisted of resistance test to temperature and $\mathrm{pH}$. Resistance test to temperature was done to select $\mathrm{LAB}$ which could still grow at $45^{\circ} \mathrm{C}$ and $37^{\circ} \mathrm{C}$ for $2-5$ days as control. Resistance test to $\mathrm{pH}$ was aimed to select $\mathrm{LAB}$ isolate which could still grow at MRSB media with acid 
environment with $\mathrm{pH}$ of 4.5 and in neutral condition $(\mathrm{pH} 7)$ as control, and further were incubated at $37^{\circ} \mathrm{C}$ for 7 days. Growth was marked by turbidity in the media (Aziz et al. 2009).

\section{Biochemical characteristic to identify the LAB}

Biochemical characteristic test to identify the $\mathrm{LAB}$ consisted of catalase test, production test of $\mathrm{CO}_{2}$, dextran, and $\mathrm{NH}_{3} . \mathrm{CO}_{2}$ production test was conducted to determine isolate capability to produce $\mathrm{CO}_{2}$ from glucose, which showed whether the isolate was homofermentative or heterofermentative. Catalase test was done to determine the isolate capability to produce catalase enzyme. Catalase test was done using hydrogenperoxide $\left(\mathrm{H}_{2} \mathrm{O}_{2}\right) 3 \%$. Dextran production test was done to determine whether the isolate could produce dextran (mucus formed) which was generally produced by Leuconostoc genus. $\mathrm{NH}_{3}$ production test was done to determine isolate which could produce ammoniac which was generally produced by Streptococcus genus (Harrigan 1998).

\section{Probiotic characteristic testing of $\mathrm{LAB}$ resistance in low pH}

LAB resistance test to low $\mathrm{pH}$ was done using PBS media by regulating the $\mathrm{pH}$ into 2 using HCL $0.1 \mathrm{~N}$ and incubated for 3 hours at $27^{\circ} \mathrm{C}$. LAB number was counted before and after the incubation. Cell number was counted by casting method using MRSA. Each test was done 3 times duple repetition (Lin et al. 2006).

\section{LAB identification using kit API CHL 50}

LAB identification using kit API CHL 50 (Biomerieux, France) was conducted to determine species of the LAB. The testing was done by 1 ose of LAB inserted into $10 \mathrm{ml}$ MRSB media then incubated at $37^{\circ} \mathrm{C}$ for 24 hours. LAB culture was centrifuged 9800 $\mathrm{x} \mathrm{g}$ for 10 minutes. Separated pellet was inserted into API 50 CHL media by sterile pipette and homogenized. The culture inserted into 50 pits of kit API CHL 50 strips. All of the pits were closed by paraffin oil to give anaerobic environment and incubated at $37^{\circ} \mathrm{C}$ for $24-48$ hours. Testing parameter was color change from blue into yellow after incubation for 24-48 hours because of formation of acid which was detected by $\mathrm{pH}$ change. Observation result was processed by software Apiweb $^{\text {TM }}$ (Gawad et al. 2010).

\section{RESULT AND DISCUSSION}

\section{LAB isolates}

LAB isolation used MRSA media, added by BCP as bacteria indicator of acid former, where the isolate which produced acid, would form yellow zone. LAB colony appearance was in form of white oval surrounded by yellow zone. It was obtained 96 isolates from North Sumatra river buffalo milk from 4 locations, namely: Lubuk Pakam (L), Medan (M), Patumba (P), and Siborong-borong (S), where each location was obtained successfully 24 isolates. LAB colony grew in the MRSA media, which was added by BCP, would seem as colony surrounded by yellow zone (Surono 2004).

\section{LAB identification}

Morphology characteristic of LAB isolate was identified through Gram staining. It showed that from 96 pure isolates which was isolated successfully from river buffalo milk, 84 isolates were positive Gram bacteria and 12 isolates were negative Gram bacteria. Test result of LAB cell form showed 19 of the 84 isolates were in oval form $(22.6 \%)$ and 65 isolates were in tube form (77.4\%). Lactic Acid Bacteria was in oval or tube form positive Gram bacteria, did not form spore, able to ferment carbohydrate, negative catalase, and microaerophilic (Axel's son 2004). In the testing of morphology characteristic from 96 isolates, 84 isolates were of positive Gram bacteria. It was followed by physiology characterizing.

Physiology characteristic testing consisted of resistance to temperature and $\mathrm{pH}$. It showed 78 of 84 isolates $(92.8 \%)$ were resistant to high temperature and 6 isolates $(7.1 \%)$ were not resistant to high temperature. Surono (2004) said that one of factors affected bacteria's growth was temperature. Elgadi et al. (2008) said that resistance of 14 isolates from fresh milk could grow at $45^{\circ} \mathrm{C}$ of temperature. According to El Soda et al. (2003), termophylic lactobacilli and cocci groups could grow at $45^{\circ} \mathrm{C}$ of temperature, but could not at $10^{\circ} \mathrm{C}$ of temperature. Mesophylic group could not grow at $45^{\circ} \mathrm{C}$ but could grow at $10^{\circ} \mathrm{C}$ of temperature. Mesophilic lactococci could grow at $10^{\circ} \mathrm{C}$ but could not grow at $45^{\circ} \mathrm{C}$ of temperature. Enterococci group could grow at $45^{\circ} \mathrm{C}$ and $10^{\circ} \mathrm{C}$ of temperature.

Resistance test to $\mathrm{pH}$ resulted in 70 isolates $(89.7 \%)$ of 78 could grow at 4.5 of $\mathrm{pH}$ and 8 isolates $(10.3 \%)$ could not grow at that $\mathrm{pH}$. According to Fowoyo \& Ogunbanwo (2010), isolate type of lactic acid which 
lived at 2 of $\mathrm{pH}$ was fewer. This type of bacteria had better ability to life in very acidic condition, and able to produce bigger organic acid number. Organic acid produced could be used to improve aroma, texture, and flavor of fermented products. In the physiology characteristic testing, 70 of 84 isolates were resistant to high temperature and low $\mathrm{pH}$. It was followed by biochemistry characteristic testing.

Result of biochemistry characteristic testing showed that in testing of production of $\mathrm{CO}_{2}$ from glucose to 70 isolates of indigenous LAB of North Sumatra river buffalo milk showed that 21 isolates $(30 \%)$ could produce $\mathrm{CO}_{2}$ (heterofermentative), whereas 49 isolates (70\%) did not produce $\mathrm{CO}_{2}$ (homofermentative). Abdulah \& Oman (2010) also reported similar result that homofermentative LAB number was found more in cow milk, cheese, and fermented milk. According to Axelsson (2004), based on fermentation pattern, LAB was divided into 3 groups, namely: homofermentative obligative, heterofermentative facultative, and heterofermentative obligate LAB.

Catalase testing showed that 52 of 70 isolates $(74.3 \%)$ did not produce $\mathrm{O}_{2}$ vesicle, so that it was grouped into negative catalase bacteria, whereas 18 isolates $(25.7 \%)$ produced $\mathrm{O}_{2}$ vesicle and grouped into positive catalase bacteria. Catalase testing was aimed to determine catalase enzyme presence in the culture of bacteria starter. Catalase enzyme production could be known by dripping $\mathrm{H}_{2} \mathrm{O}_{2}$ on bacteria preparate. If there was gas vesicle, it showed that the bacteria released $\mathrm{O}_{2}$ and grouped into positive catalase bacteria. Bacteria that did not release the $\mathrm{O}_{2}$ vesicle showed that the bacteria had peroxidase enzyme which could prevent $\mathrm{O}_{2}$ production and it was stated as negative catalase bacteria (Surono 2004).

Testing result of production of dextran from sucrose to 52 isolates of indigenous LAB of North Sumatra river buffalo milk showed that 4 isolates $(7.7 \%)$ produced dextran positively, whereas 48 isolates $(92.3 \%)$ did not produce dextran. It was concluded that the LAB isolates which did not produce dextran did not included into Leuconostoc group. One of characters of the Leuconostoc is dextran production visualized as mucoid. Dextran was defined as water soluble polygosacaride formed from $\alpha 1-6$ glucosides with proportion of 0-20\% (Sarwat et al. 2008).

Testing of 48 isolates in producing $\mathrm{NH}_{3}$ from arginine showed that isolates $(14.6 \%)$ produced $\mathrm{NH}_{3}$ positively, whereas 41 isolates $(85.4 \%)$ did not produce $\mathrm{NH}_{3}$. Isolates that produced $\mathrm{NH}_{3}$ did not selected to further testing because by producing $\mathrm{NH}_{3}$, it was feared will affect the product aroma. Tserovska et al. (2002) said that $60 \%$ of LAB from cheese and milk able to produce $\mathrm{NH}_{3}$ from arginine.

Research result of LAB identification by biochemistry characteristic testing showed that it was obtained 40 of $70 \mathrm{LAB}$ isolates which meet LAB characteristics, so that it was continued to further test. The further test was probiotic characterizing to evaluate $\mathrm{LAB}$ resistance to low $\mathrm{pH}$. LAB 41st characteristic identified successfully was presented in Table 1.

\section{LAB resistance testing of low $\mathrm{pH}$}

$\mathrm{LAB}$ isolates resistance to low $\mathrm{pH}$ was one of probiotic conditions, because stress of probiotic LAB was started at the time the LAB exposured by acidity condition of the gastric. According to Wildman \& Medeiros (2000), gastric had around 2 of $\mathrm{pH}$. Resistance testing of low $\mathrm{pH}$ was needed to determine capability of LAB culture of isolates of river buffalo milk to survive to the gastric acidity.

Figure 1, shows LAB population before and after exposured to low $\mathrm{pH}$ which experienced a population decline of $1.24 \pm 0.68 \mathrm{log} \mathrm{cfu} / \mathrm{ml}$. In other study, in LAB isolate from buffalo milk in India showed just 2 of 3 isolates tested that survived at 2 of $\mathrm{pH}$ for 3 hours incubation, whereas 1 isolate only survived for 1.5 hours (Shafakatullah \& Chandra 2014). In the testing of LAB isolate from breast milk, all of the isolates experienced number cell decreasing with different decreasing value to each isolate with decreasing range around 0.57-7.24 $\log \mathrm{cfu} / \mathrm{ml}$ (Nuraida et al. 2011). Resistance testing at low $\mathrm{pH}$ of LAB isolate from goat milk showed that all of the tested isolates experienced population decrease less than 1 log $\mathrm{cfu} / \mathrm{ml}$ (Setyawardani et al. 2014).

Ability to survive in better acidic condition for each isolate was showed by different cell number change of all tested isolates. According to Nuraida (2011), isolate ability to survive at this acidic condition was strain dependent. This was due to cytoplasm membrane difference of each bacteria. The difference affected characteristic and permeability of membrane.

Under acidic condition, LAB could maintain acidity of cytoplasm, so that protein and enzyme in the cell could still work optimally. LAB isolate was adaptable in low $\mathrm{pH}$ because it had an internal cell $\mathrm{pH}$ regulation. This can be achieved by existence of enzyme synthesis and producing proton $(\mathrm{H}+)$ from inside of the cell that was occurred through ATP hydrolysis (H+-ATPase) process. The Lactic Acid Bacteria was survive from acid damage because the existence of histidine decarboxylase and arginine of deaminase enzyme. LAB tolerance of high acidity was caused by its capability to maintain more alkaline $\mathrm{pH}$ of cytoplasm than extracellular pH (Pan et al. 2011).

Result showed of North Sumatra river buffalo milk that had the best resistance or experienced lowest population decrease were isolate L12, L16, L17, L19, L20, M10, P8, S3, S19, and S20. The 10 of that isolates were selected to be tested of LAB species using API test CHL 50. 
Table 1. Identification of LAB isolates from North Sumatra river buffalo milk

\begin{tabular}{|c|c|c|c|c|c|c|c|c|}
\hline $\begin{array}{l}\text { Isolate } \\
\text { Code }\end{array}$ & Catalase & Gram & $\begin{array}{l}\text { Cell } \\
\text { Form }\end{array}$ & $\begin{array}{l}\mathrm{pH} \\
4,5\end{array}$ & $\begin{array}{c}\text { Temperature } \\
\left(45^{\circ} \mathrm{C}\right)\end{array}$ & $\begin{array}{c}\mathrm{CO}_{2} \\
\text { Production. }\end{array}$ & $\begin{array}{c}\mathrm{NH}_{3} \\
\text { Production }\end{array}$ & $\begin{array}{c}\text { Dextran } \\
\text { Production }\end{array}$ \\
\hline L7 & - & + & tube & + & + & + & - & - \\
\hline L8 & - & + & tube & + & + & - & - & - \\
\hline L11 & - & + & tube & + & + & + & - & - \\
\hline L12 & - & + & tube & + & + & - & - & - \\
\hline L13 & - & + & tube & + & + & - & - & - \\
\hline L14 & - & + & oval & + & + & + & - & - \\
\hline L15 & - & + & oval & + & + & - & - & - \\
\hline L16 & - & + & tube & + & + & + & - & - \\
\hline L17 & - & + & tube & + & + & + & - & - \\
\hline L18 & - & + & oval & + & + & + & - & - \\
\hline L19 & - & + & tube & + & + & + & - & - \\
\hline L20 & - & + & tube & + & + & - & - & - \\
\hline M1 & - & + & tube & + & + & - & - & - \\
\hline M2 & - & + & oval & + & + & + & - & - \\
\hline M3 & - & + & tube & + & + & - & - & - \\
\hline M10 & - & + & tube & + & + & - & - & - \\
\hline M11 & - & + & tube & + & + & - & - & - \\
\hline M12 & - & + & oval & + & + & + & - & - \\
\hline M14 & - & + & oval & + & + & - & - & - \\
\hline $\mathrm{P} 1$ & - & + & tube & + & + & + & - & - \\
\hline P2 & - & + & tube & + & + & - & - & - \\
\hline P4 & - & + & tube & + & + & - & - & - \\
\hline P5 & - & + & tube & + & + & + & - & - \\
\hline P6 & - & + & tube & + & + & - & - & - \\
\hline P7 & - & + & tube & + & + & + & - & - \\
\hline P8 & - & + & oval & + & + & - & - & - \\
\hline P9 & - & + & tube & + & + & + & - & - \\
\hline $\mathrm{P} 10$ & - & + & tube & + & + & + & - & - \\
\hline P11 & - & + & tube & + & + & - & - & - \\
\hline P13 & - & + & tube & + & + & - & - & - \\
\hline $\mathrm{P} 14$ & - & + & oval & + & + & + & - & - \\
\hline S3 & - & + & tube & + & + & - & - & - \\
\hline S6 & - & + & tube & + & + & + & - & - \\
\hline S9 & - & + & tube & + & + & - & - & - \\
\hline $\mathrm{S} 10$ & - & + & tube & + & + & - & - & - \\
\hline $\mathrm{S} 11$ & - & + & tube & + & + & + & - & - \\
\hline $\mathrm{S} 12$ & - & + & tube & + & + & + & - & - \\
\hline S13 & - & + & oval & + & + & - & - & - \\
\hline S14 & - & + & oval & + & + & + & - & - \\
\hline S19 & - & + & oval & + & + & - & - & - \\
\hline S20 & - & + & tube & + & + & - & - & - \\
\hline
\end{tabular}

$\mathrm{L} \quad=$ Lubuk Pakam

$\mathrm{M}=$ Medan

$\mathrm{P} \quad=$ Patumbak

$\mathrm{S}=$ Siborong-borong

$+\quad=$ There is a growth

$=$ There is no growth 


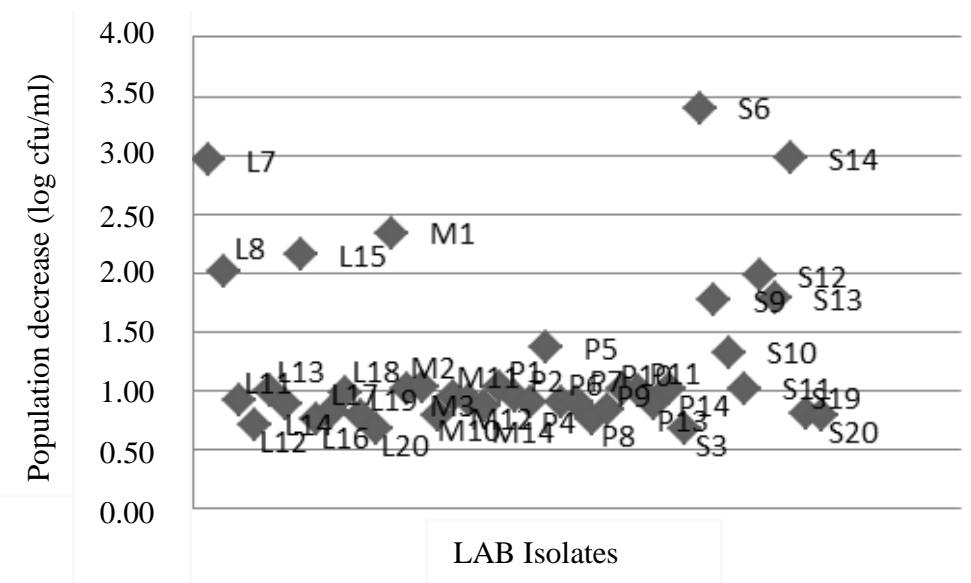

Figure 1. Population decrease of LAB after it exposured by low $\mathrm{pH}$

Table 2. Identification of LAB species using API test CHL 50

\begin{tabular}{llc}
\hline $\begin{array}{l}\text { Code of } \\
\text { isolate }\end{array}$ & Name of LAB species & $\begin{array}{c}\text { Percentation } \\
(\%)\end{array}$ \\
\hline L12 & Lactobacillus pentosus & 94.4 \\
L16 & Lactobacillus brevis & 96.6 \\
L17 & Lactobacillus brevis & 96.6 \\
L19 & Lactobacillus brevis & 99.5 \\
L20 & Lactobacillus plantarum & 99.9 \\
M10 & Lactobacillus plantarum & 99.9 \\
P8 & Lactococcus lactis & 96.2 \\
S3 & Lactobacillus plantarum & 99.9 \\
S19 & Lactococcus lactis & 96.2 \\
S20 & Lactobacillus plantarum & 98.3 \\
\hline
\end{tabular}

$\mathrm{L}=$ Lubuk Pakam; M= Medan; $\mathrm{P}=$ Patumbang; $\mathrm{S}=$ Siborong-borong

\section{LAB identification using API test CHL 50}

Identification of LAB species using API test CHL 50 was done to the best 10 isolates based on resistance testing to low $\mathrm{pH}$. It was presented completely in Table 2. Testing by API test CHL 50 resulted in 4 LAB species, namely: Lactobacillus plantarum (4 isolates), Lactobacillus brevis (3 isolates), Lactobacillus pentosus (1 isolate) and Lactococus lactis (2 isolates).

L12 isolate was identified as Lactobacillus pentosus with acid level of 94.4\%, isolate L16, L17, and L19 were identified as L. brevis with acid level of $96.6 \%$; $96.60 \%$, and $99.50 \%$, respectively. Isolate L20, M10,
$\mathrm{S} 3$, and S2 were identified as L. plantarum with same acid level of $96.20 \%$. Based on genotyping testing result by analysis of gene 16 sequences of S rRNA and after alignment of nucleotide sequence from selected isolate (isolate S3) on GenBank database showed that S3 isolate had similarity to the isolates of L. plantarum strain JCM 1149 with access code NCBI BLAST NR. 117813.1 with similarity level of 99\% (unpublished data). This result showed that isolation and identification of API test CHL 50 was in line with the genotyping sequence of gene $16 \mathrm{~S}$ rRNA.

Testing result of species identification using API test CHL 50 of isolates from buffalo milk in India showed that there were 6 LAB species, namely: $L$. bulgaricus, L. plantarum, L. lactis, L. acidophilus, $L$. brevisand L. rhamnosus (Tambekar et al. 2009; Singh \& Sharma 2009; Azis et al. 2009; Syafakatullah et al. 2014). LAB species testing of processed buffalo milk (cruds) in Indonesia showed that there were $6 \mathrm{LAB}$ species, namely: L. brevis, L. plantarum, L. casei, L. paracasei, Lactococcus lactis, Leuconostoc mesenteroides (Surono 2003), whereas Sunaryanto \& Mawoto (2012) identified successfully one of LAB species, namely: L. plantarum.

\section{CONCLUSION}

In this research $41 \mathrm{LAB}$ isolates from North Sumatra river buffalo milk were isolated and identified. They survived successfully in low $\mathrm{pH}$. Identification result of species tested by API test CHL 50 showed that from selected 10 isolates, 4 species were identified successfully, namely: Lactobacillus plantarum, $L$. brevis, L. pentosus and Lactococus lactis. 


\section{ACKNOWLEDGEMENTS}

The author gratefully appreciate KKP3N program of Indonesian Agency for Agricultural Research and Development (IAADR), Ministry of Agriculture through SPK No.: 62/PL.220/I.1/3/2014.K on 10 March 2014 funded this research.

\section{REFERENCES}

Abbas MM, Mahasneh AM. 2015. Functional characteristics of Lactobacillus strains isolated from camel's milk. Br J Med Med Res. 7:25-39.

Abdullah SA, Osman MM. 2010. Isolation and identification of lactic acid bacteria from raw cow milk, White Cheese and Rob in Sudan. Pak J Nutr. 9:1203-1206.

Ahmed T, Kanwal R, Athar IH, Ayub N. 2002. Isolation and identification of lactic acid producing bacteria from camel milk. Pak Vet J. 22:141-144.

Antara NS, Dibia IN, Aryanta WR. 2009. Karakterisasi Bakteri Asam Laktat yang diisolasi dari susu kuda Bima. Agritech. 29:1-9.

Axelsson L. 2004. Lactic acid bacteria: Classification and physiology. Dalam: Salminen S \& Von Wright A, editor. Lactic Acid Bacteria: Microbiology and Functional Aspects. New York (USA): Marcel Dekker Inc. p. 1-73.

Aziz T, Khan H, Bakhtiar SM, Naurin M. 2009. Incidence dan relative abundance of lactic acid bacteria in raw milk of buffalo, cow and sheep. J Anim Plant Sci. 19:168-173.

Damayanthi E, Yopi, Hasinah H, Setyawardani T, Rizqiati H, Putra S. 2014. Karakteristik susu kerbau sungai dan rawa di Sumatera Utara. JIPI. 19:67-73.

Elgadi Z, Abdel GWS, Dirar NA. 2008. Isolation and identification of lactic acid bacteria and yeast from raw milk in Khartoum State (Sudan). Res J Microbiol. 3:163-168

ElSodaM, AhmedN, Omran N, Osman G, Morsi A 2003.Isolation, identification and selection of lactic acid bacteria cultures for cheese making. Emir J Agric Sci 15:51-71.

Fowoyo PT, Ogunbanwo ST. 2010. Phenotypic diversity of lactic acid bacteria isolated from Massa, a fermented maize dough. Afr J Microbiol Res. 4:2682-2691.

Gawad AE, Fatah AE, Rubayyi A. 2010. Identification and characterization of dominant lactic acid bacteria isolated from traditional rayeb milk in Egypt. J Am Sci. 6:728735.

Harrigan WF. 1998. Laboratory methods in food microbiology. New York (USA): Academic Press.

Iranmanesh M, Ezzatpanah H, Mojgani N, Torshizi MAK, Aminafshar M, Maohamadi M. 2012. Isolation of lactic acid bacteria from Ewe milk, traditional yoghurt and sour buttermilk in Iran. Eur J Food Res Rev. 2:79-92
Khedid K, Faid M, Mokhtari A, Soulaymani A, Zinedine A. 2009. Characterization of lactic acid bacteria isolated from the one humped camel milk produced in Morocco. Microbiol Res. 164:81-91.

Kumar R, Pandey S, Kapoor P, Awasthi S, Bhatnagar T. 2014. Isolation and characterization of endemic strains of Lactobacillus sp. and evaluation of their probiotic activity. Int J Curr Microbiol App Sci. 3:907-916.

Lin WH, Wang CFH, Chen LW, Tsen HY. 2006. Viable counts, characteristic evaluation for commercial lactic acid bacteria product. Food Microbiol. 23:78-81.

Nuraida L, Winarti S, Hana, Prangdimurti E. 2011. Evaluasi in vitro terhadap kemampuan isolate bakteri asam laktat asal air susu ibu untuk mengasimilasi kolesterol dan mendekonjugasi garam empedu. J Teknologi Industri Pangan. 22:46-52.

Pan DD, Zeng QX, Yan YT. 2011. Characterisation of Lactobacillus fermentum SM-7 isolated from koumiss, a potential probiotic bacterium with cholesterol-lowering effects. J Sci Food Agric. 91:512-518.

Patel N, Patel V. 2012. Isolation, identification and antimocrobial activity determination of lactic acid bacteria from buffalo milk in Gujarat state India. Int $\mathbf{J}$ Pharm World Res. 3:1-8.

Rizqiati H, Sumantri C, Noor RR, Damayanthi E, Rianti EI. 2015. Characteristics of indigenous probiotic from river buffalo milk in North Sumatera Indonesia. Int $\mathrm{J}$ Sc Basic Appl Res. 22:113-120.

Roberfroid MB. 2000. Prebiotics and probiotics: are they functional food?. Am Clin Nutr. 71:1682S-1687S.

Sarwat F, Ali S, Qader, Aman A, Ahme N. 2008. Production and characterization of a unique dextran from an indigenous Leuconostoc mesenteroides CMG713. Int J Biol Sci. 4:379-386.

Shafakatullah N, Chandra M. 2014. Screening of row buffalo's milk from Karnataka for potential probiotic strains. Res J Resecnt Sci. 3:73-78.

Sharma R, Sanodiya BS, Thakur GS, Jaiswal P, Pal S, Sharma A, Bisen PS. 2013. Characterization of lactic acid bacteria from raw milk samples of cow, goat, sheep, camel and buffalo with special eludation to lactic acid production. Br Microbiol Res J. 3:743-752.

Singh GP, Sharma RR. 2009. Dominating species of Lactobacilli and Leuconostoc present among the lactic acid bacteria of milk of different cattles. Asian J Exp Sci. 23:173-179.

Sugitha IM, Arisandhi PW, Sinaga KYRH. 2011. Isolasi Bakteri Asam Laktat susu kuda liar sebagai starter dadih. The Excellence Research Universitas Udayana. Bali. p. 121-125

Sujaya N, Ramona Y, Widarini NP, Suariani NP, Utama Dwipayanti NM, Nocianitri KA, Nursini NW. 2008. Isolasi dan karakterisasi bakteri asam laktat dari susu kuda Sumbawa. J Vet. 9:52-59. 
Sunaryanto R, Marwoto B. 2013. Isolasi, identifikasi dan karakterisasi bakteri asam laktat dari dadih susu kerbau. J Sains Teknologi Indonesia. 14:228-233.

Surono IS. 2003. In vitro probiotic properties of indigenous dadih lactic acid bacteria. Asian-Aust J Anim Sci. 16:726-731.

Surono IS. 2004. Probiotik: Susu fermentasi dan kesehatan. Jakarta (Indonesia): PT Tri Cipta Karya.

Setyawardani T, Rahayu WP, Maheswari RRA, Palupi NHS. 2013. Identification and characterization of probiotic lactic acid bacteria isolated from indigenous goat milk. J Anim Prod. 1:57-63.
Tambekar DH, Bhutada SA, Choudhary SD, Khond MD. 2009. Assessment of potensial probiotic bacteria isolated from milk of domestic animals. J Appl Bio. $15: 815-819$.

Tserovska L, Stefanova S, Yordanova T. 2002. Identification of lactic acid bacteria isolated from katyk, goat's milk and cheese. J Cult Coll. 3:48-52.

Wildman REC, Medeiros DM. 2000. Advanced human nutrition. New Jersey (USA): CRC Press LLC, Boca Raton. 